\title{
COMPARATIVE MORPHOLOGY AND ANATOMY OF THE LEAF AND STEM OF PEPEROMIA DAHLSTEDTII C.DC., OTTONIA MARTIANA MIQ. AND PIPER DIOSPYRIFOLIUM KUNTH (PIPERACEAE)
}

\section{MORFOLOGIA Y ANATOMIA COMPARATIVA DE LA HOJA Y TALLO DE PEPEROMIA DAHLSTEDTII C.DC., OTTONIA MARTIANA $M I Q . Y$ PIPER DIOSPYRIFOLIUM KUNTH (PIPERACEAE)}

\author{
L. A. Souza, I. S. Moscheta \& J. H. G. Oliveira ${ }^{1}$ \\ ${ }^{1}$ Departamento de Biologia, Centro de Ciências Biológicas, Universidade Estadual de Maringá, Avenida Colombo, \\ 5790 (87020-900) Maringá, Paraná, Brazil. E-mail: lasouza@uem.br
}

\begin{abstract}
The genera and species of Piperaceae show a considerable structural diversity of leaves and especially stems. This paper presents a comparative morphological and anatomical study of the leaves and stems of three common Brazilian species of this family (Peperomia dahlstedtii C.DC., Ottonia martiana Miq. and Piper diospyrifolium Kunth), the vegetative organs of which have previously been little studied. The collected plant material was fixed in FAA, cut freehand and stained in safranin and astra blue. P. dahlstedtii is an epiphyte and has a herbaceous stem with whorled leaves phyllotaxis and a polystelic structure, a multiseriate adaxial leaf epidermis and calcium oxalate monocrystals in parenchyma and collenchyma petiole cells. $O$. martiana and $P$. diospyrifolium showed strong similarities, both being terrestrial plants, with alternate phyllotaxis, stele with medullary bundles and dorsiventral leaves with an epidermis and subepidermic layer. In $O$. martiana the stomatal complex is staurocytic and presented silica crystal sand in parenchyma petiole and midrib cells. In $P$. diospyrifolium the stomatal complex is tetracytic and there are calcium oxalate raphide crystals in the parenchyma of the petiole and midrib cells. On the other hand, the three species show some structural likenesses in that all have hypostomatic and dorsiventral leaves, oily cells in petiole and mesophyll, secretory trichomes and an endodermis with Casparian strips.
\end{abstract}

KeYwords: Crystal cells, epidermis, stele, petiole.

RESUMEN

Los géneros y las especies de Piperaceae muestran una notoria diversidad estructural en sus hojas, y en particular en tallos. Este trabajo presente presenta un estudio comparativo morfológico y anatómico del tallo y hoja de tres especies de esta familia (Peperomia dahlstedtii C.DC., Ottonia martiana Miq. y Piper diospyrifolium Kunth) que son frecuentes en los bosques brasileños, sin que sus órganos vegetativos hubiesen sido previamente examinados anatómicamente. El material fue fijado en FAA, cortado a mano y coloreado con safranina y azul de astra. P. dahlstedtii es un epífito que posee un tallo herbáceo con filotaxia verticilada y estructura polistélica, hoja con epidermis adaxial multiseriada y monocristal de oxalato de calcio en células parenquimáticas y colenquimáticas del pecíolo. $O$. martiana y $P$. diospyrifolium presentan muchas semejanzas, siendo ambas plantas terrestres con filotaxia alterna, estela con haces medulares y hoja dorsiventral con epidermis y subepidermis. En $O$. martiana el aparato estomático es estaurocítico y presenta cristal de sílice en células parenquimáticas del pecíolo y vena media. En $P$. diospyrifolium el aparato estomático es tetracítico con presencia de rafidios en la parénquima del pecíolo y vena media. Por otro lado, las tres especies muestran cierta semblanza estructural, como hojas hipostomáticas y dorsiventrales, células con aceite en el peciolo y lámina, tricomas glandulares y endodermis provista de banda de Caspary.

Palabras claves: Cristal, epidermis, estela, pecíolo. 
Vegetative morphology and anatomy of Piperaceae: SouzA, L. A. ET AL.

\section{INTRODUCTION}

The family Piperaceae is of considerable economic importance, as a large number of its members are of medicinal or culinary interest. The Piperaceae are represented in Brazil by five genera and approximately 460 species (Barroso et al. 1978). They are erect or scandent shrubs, small trees, or succulent, terrestrial or epiphytic herbs, with nodose stems. Leaves are petiolate or infrequently subsessile, and stipules adnate to the petiole or absent (Yuncker 1972).

The genus Peperomia Ruiz \& Pav. includes both epiphytic and terrestrial species. It consists of herbs and accounts for about 63 species in Paraná State, with almost half of them associated with dense ombrophila forest (Yuncker 1974; Takemori 2002). The genus Ottonia Spreng. possesses shrubs or subshrubs, with leaves narrowly lanceolate to broadly ovate or elliptic (Yuncker 1973). The genus Piper L. includes shrubs or small trees, occasionally scandent, but rarely subherbaceous, with a nodose stem, and simple, entire and alternate leaves (Yuncker 1972).

Morphological and anatomical studies of vegetative organs of Piperaceae are relatively scarce. Datta \& Dasgupta (1977) carried out work of broad scope on the leaf anatomy of Piper and Peperomia, but most other studies have focused on specific aspects of anatomy or morphology (Bond 1931; Langhammer 1970; Nascimento \& VilhenaPotiguara 1999; Silva \& Machado 1999), or on a more limited range of taxa (Salatino \& Silva 1975; Gobbi 2003).

The most outstanding anatomical character in the Piperaceae is the nature of the vascular bundles in the axis. These are usually scattered like those of the Monocotyledons, but several more or less distinct arrangements occur in the different genera and species (Metcalfe \& Chalk 1957). Judd $e t$ al. (1999) regarded the Piperales as paleoherbs, displaying some traits typically associated with monocots. The leaves of Piperaceae species also show structural diversity, especially between Peperomia and the genera Piper and Ottonia.

This paper presents a comparative morphological and anatomical study of three common Brazilian species of Piperaceae: Peperomia dahlstedtii C.DC., Ottonia martiana Miq. and Piper diospyrifolium Kunth. Although all three of these species are common in forest remnants in the northwest region of Paraná State, their leaves and stems have previously been little studied. The epiphyte Peperomia dahlstedtii occurs on the bark of several tree species, including Gallesia integrifolia (Spreng.) Harms ("pau-d'alho"), [Phytolaccaceae], Cedrela fissilis Vell. ("cedro") [Meliaceae], Nectandra megapotamica (Spreng.) Mez ("canelinha-amarela") [Lauraceae] and Cabralea canjerana (Vell.) Mart. ("canjerana”), Meliaceae. Ottonia martiana and Piper diospyrifolium are terrestrial species, often forming small thickets in the forest understorey.

\section{MATERIALS AND METHODS}

The collection of the botanical material and the field observations of P. dahlstedtii, O. martiana and $P$. diospyrifolium were carried out in "Horto Florestal de Maringá", Paraná State (Brazil), a 37 ha forest remnant.

The morphological description of the leaves of the species was based on Rizzini (1977). The analysis of the stem and leaf structure was done using freshly-collected material or material fixed in FAA 50 (Johansen 1940). This material was cut freehand or in a rotative microtome to make semipermanent and permanent slides for the microscopic studies, carried out according to the usual techniques. Sections were stained in astra blue, safranin and hematoxylin (Johansen 1940; Dnyansagar 1958).

Specific microchemical tests were done in stems and leaves for calcium oxalate (10\% hydrochloric acid) (Chamberlain 1932), silica (phenol) (Johansen 1940) and lipid substances (sudam IV) (Johansen 1940; Cutler 1978).

Stomatal, epidermical cell and trichome frequency $\left(\mathrm{mm}^{-2}\right)$ were counted in quadrats of 0.04 $\mathrm{mm}^{2}$, using a reflex camera. In the middle region of the blade, five fields of ten leaves were observed, totalling 50 fields for each leaf face per species. The Salisbury formula was used to calculate the stomatal index (Wilkinson 1979).

Drawings were made using an optical microscope equipped with a reflex camera. They were prepared on the same micrometric scale for all samples.

Exsiccata of the studied species were depos- 
Gayana Bot. 61(1), 2004

ited in the Herbarium of Universidade Estadual de Maringá (Paraná State, Brazil) and registered as follows:

Peperomia dahlstedtii C.DC. - BRAZIL. Paraná. Maringá, Horto Florestal, A. L. M. Albiero 9134 (HUM).

Ottonia martiana Miq. - BRAZIL. Paraná. Maringá, Horto Florestal, A. L. M. Albiero 8974 (HUM).

Piper diospyrifolium Kunth - BRAZIL. Paraná. Maringá, Horto Florestal, A. L. M. Albiero 9392 (HUM).

\section{RESULTS AND DISCUSSION}

STEM AND LEAF MORPHOLOGY

The stem of Peperomia dahlstedtii develops adventitious roots at the nodes, that penetrate the bark of the host plant. The stem is green and is pentangular in cross-section, and has a marked nodal structure. Each node presents three leaves, characterizing the phyllotaxis as whorled (Fig. 1). Racemose inflorescences are axillary with two or three small green bracteoles in the axial base. The leave is broadly lanceolate, with an acute base and apex (Fig. 1).

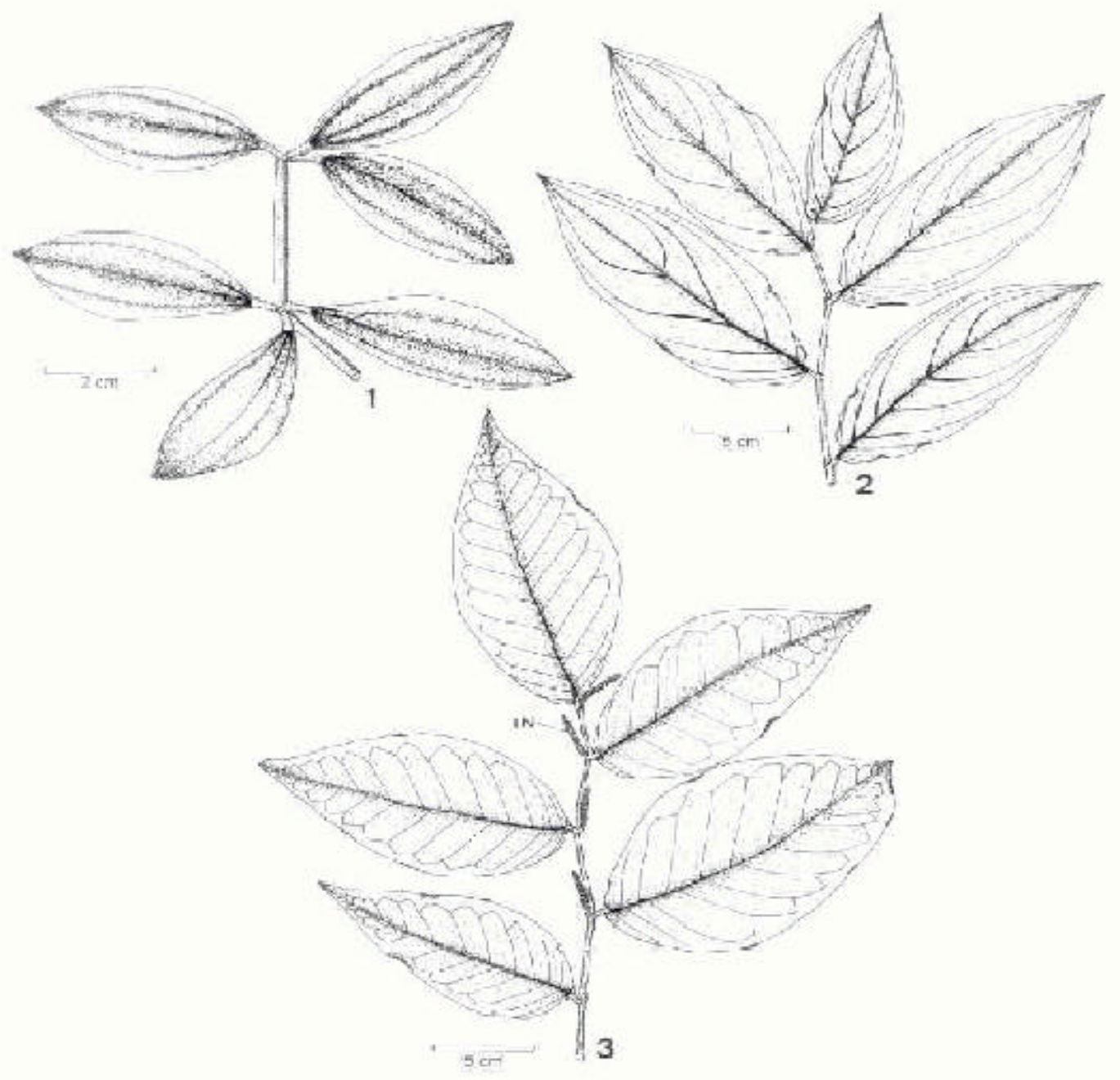

FIgures 1-3. Branches of (1) P.dahlstedtii; (2) O. martiana; (3) P. diospyrifolium. (IN = inflorescence). 
Vegetative morphology and anatomy of Piperaceae: SouzA, L. ET AL.

The whorled phyllotaxis and leaf morphology of $P$. dahlstedtii are similar to the Paraná species analyzed by Takemori (2002): P. catharinae Miq. and $P$. quadrifolia (L.) Kunth. P. dahlstedtii differs, however, from the other two species investigated by this author ( $P$. emarginella (SW.) C.DC. and $P$. rotundifolia (L.) Kunth.), which possessed alternate phyllotaxis and rounded leaves, with a frequently emarginate apex.

Ottonia martiana is a subshrub, with a green cylindrical nodose stem, helicoidal alternate phyllotaxis and leaf-opposed racemose inflorescences (Fig. 3). Piper diospyrifolium also presents alternate phyllotaxis (Fig. 2) and it differs from $O$. martiana by presenting a shrub habit and a woody stem with lenticels. The two species present a pla- giotropic organ similar to a stolon. The stolon is, according to Font-Quer (1985), a lateral and horizontal branch that sprouts from the stem base. It develops at the soil surface, takes root, and eventually gives rise to new individuals through death of its intermediate portion, thus spreading the plant vegetatively. However, it is necessary to analyze the structure of this plagiotropic organ. Preliminary observations suggested that it is stem nature in $O$. martiana and root in P.diospyrifolium.

$O$. martiana and $P$. diospyrifolium have petiolate leaves (Figs. 2, 3). The blade was ovate or lanceolate-ovate, with a non-equilateral base and an apex varying from acuminate to cuspidate (Figs. 2, 3). Lanceolate leaves can also occur in $O$. martiana.

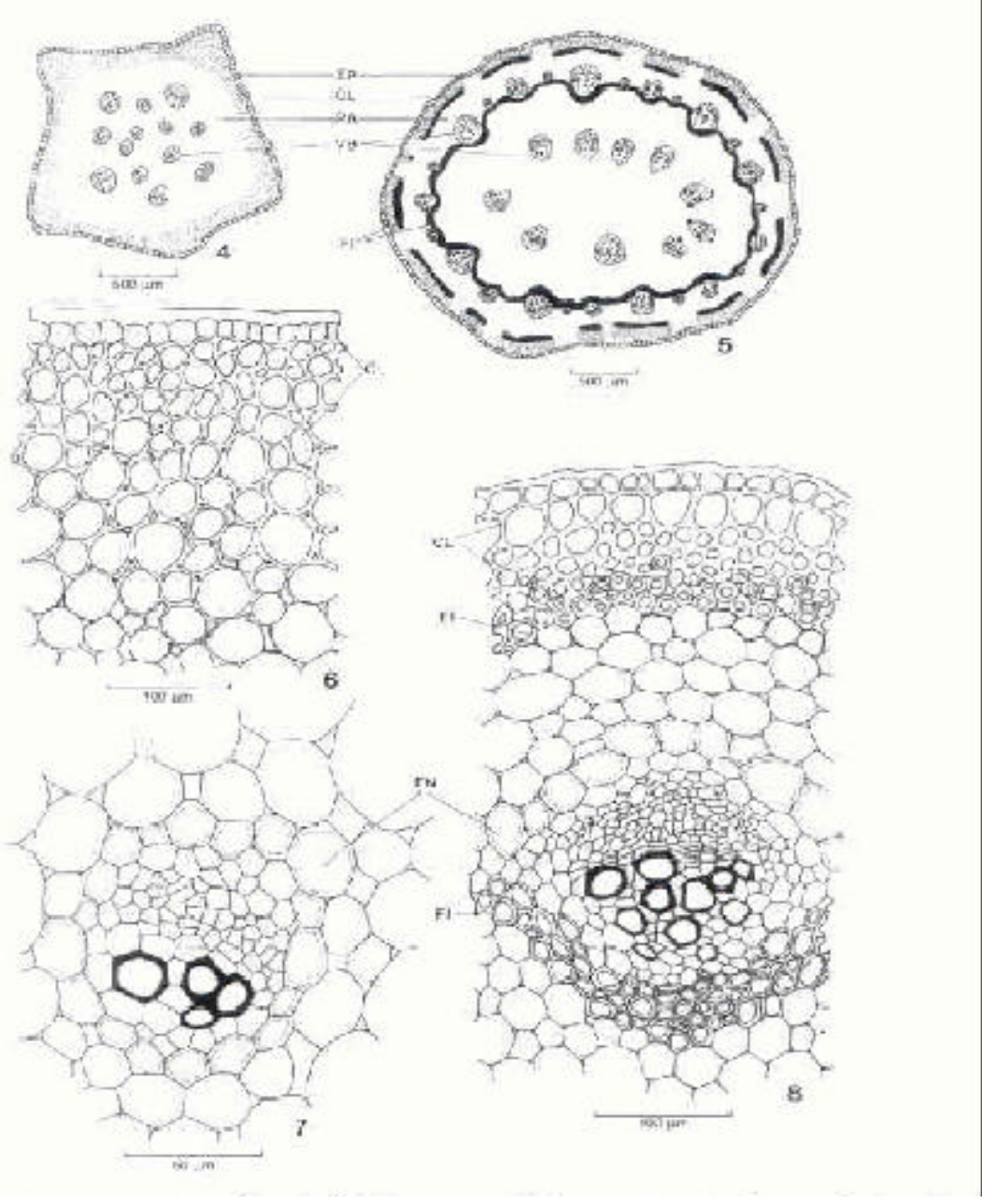

FIgURES 4-8. Stem structure in cross-section. Figs. 4, 6, 7 show overall diagram detail and vascular bundle of P.dahlstedtii, respectively. Figs. 5, 8 show overall diagram and detail respectively of $O$. martiana $(\mathrm{CL}=$ collenchyma, $\mathrm{EN}=$ endodermis, $\mathrm{EP}=$ epidermis, FI = fibers; $\mathrm{PA}=$ parenchyma, $\mathrm{VB}=$ vascular bundle). 
Gayana Bot. 61(1), 2004

STEM ANATOMY

The stem of P.dahlstedtii has a polystelic structure (Fig. 4). Each collateral vascular bundle and fascicular cambium is covered with a uniseriate parenchymatous pericycle and an endodermis with Casparian strips (Fig. 7). On the other hand, $O$. martiana and P. diospyrifolium stems have steles with two concentric rings of collateral vascular bundles; the outer vascular bundles are interconnected by sclerenchyma (Figs. 5, 8). In these species, an endodermis with Casparian strips and a parenchymatous pericycle covered the central cylinder (Fig. 8). Starting from the second or third node in $O$. martiniana and P. diospyrifolium, a fascicular cambium and periclinal divisions of the interfascicular cells of the pericycle were common.

Piperaceae in general, which can be considered paleoherbs (Judd et al. 1999), have steles that approximate those of monocots (Metcalfe \& Chalk
1957). Polysteles, as found in P. dahlstedtii (Fig. 4) are common in Poaceae (Gramineae) species. In $O$. martiana and P. diospyrifolium, with medullary bundles arranged in a circle (Fig. 5), the stele is similar to that of other monocots. Eames \& MacDaniels (1953) consider anomalous stem structure in the dicotyledons to be sometimes due to the presence of medullary bundles, as they occur in Piperaceae.

An endodermis in the stem has also been recorded for other species of Piper (Bond 1931) and Peperomia (Takemori 2002). However, there is no record of stem endodermis for Ottonia species. Bond (1931) tentatively concluded that the endodermis is a vestigial structure of no primary importance in the internal economy of the stem. Similarly, Lersten (1997) revised the occurrence of the endodermis with a Casparian strip in the stem and leaf of vascular plants and considered that this strip in aerial organs has no known functional role.
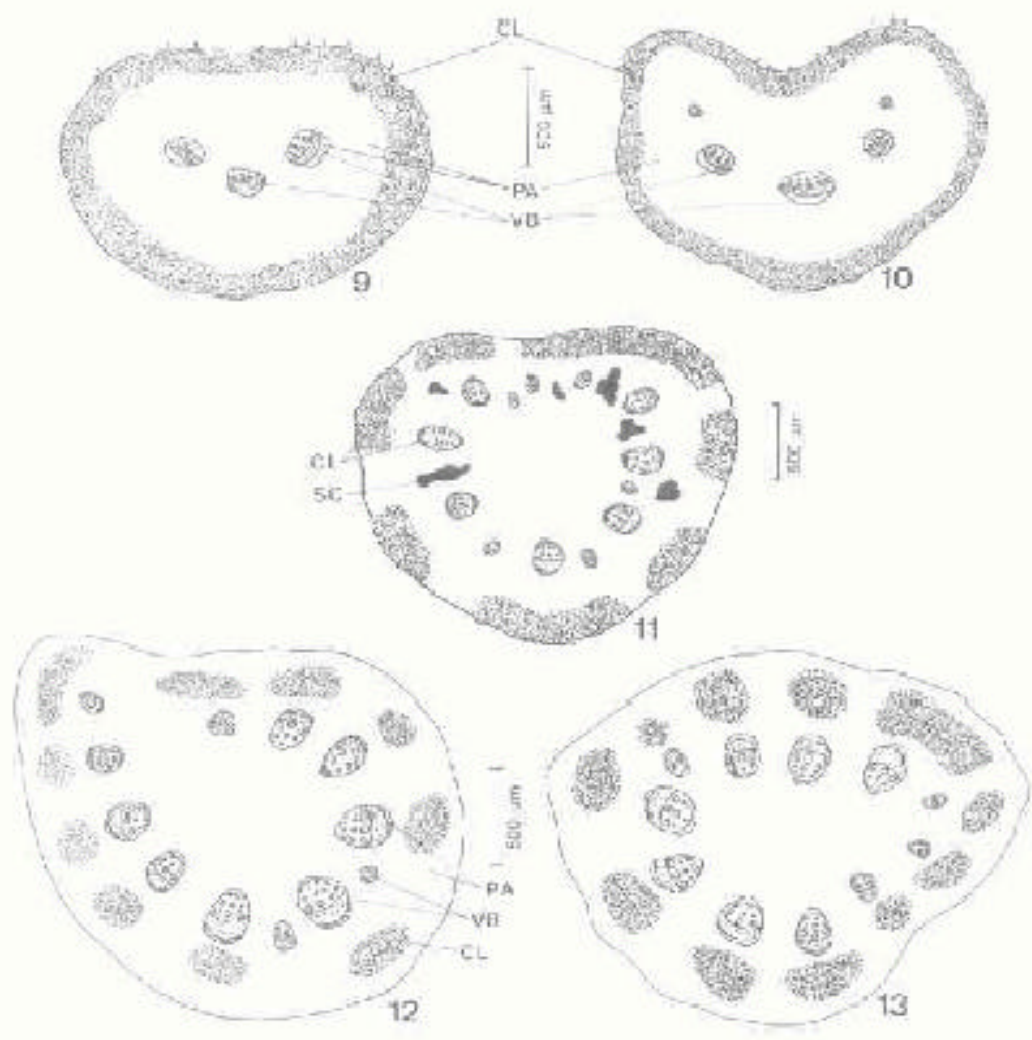

Figures 9-13. Petiole structure diagrams in cross-section. Figs. 9, 10 show P. dahlstedtii petiole base and apex. Fig. 11 shows $O$. martiana petiole base. Figs. 12, 13 show $P$. diospyrifolium petiole base and middle region $(\mathrm{CL}=\mathrm{collen}-$ chyma, $\mathrm{PA}=$ parenchyma, $\mathrm{SC}=$ sclerenchyma, $\mathrm{VB}=$ vascular bundle). 
Vegetative morphology and anatomy of Piperaceae: SouzA, L. ET AL.

The P.dahlstedtii epidermis is unilayered (Fig. 6 ), with a cuticle, secretory trichomes and periclinal thick-walled cells. The cortex of this species possesses parenchyma and subepidermic collenchyma arranged in continuous strata (Figs. 4, 6). The epidermis (Figs. $5,8)$ of the other two species is also uniseriate with glandular trichomes, but has cells with thinner outer periclinal walls than those of $P$. dahlstedtii. In the cortex of $O$. martiana and $P$. diospyrifolium, there is also parenchyma and the collenchyma occur in longitudinal strips (Fig. 8). The O. martiana cortical collenchyma is subepidermic (Fig. 5) and that of $P$. diospyrifolium is separated from the epidermis. Some inner collenchymatous cells of these two species are differentiated in the fibers (Figs. 5, 8). The differentiation of collenchymatous cells in the fibers (in the lower nodes) is cited for the caulinar cortex of Piper by Metcalfe \& Chalk (1957) and not for Ottonia species. Nascimento \& Vilhena-Potiguara (1999) also describe the sclerification of the cortical collenchyma in Piper hispidinervium C.DC. Fahn (1990) considers the sclerification of the collenchyma common in dicot stems and petioles, describing how this process occurs through centripetal and centrifugal lamellation of the cell wall.

LEAF ANATOMY

The P. dahlstedtii petiole resembles the stem, ex- cept for the number and arrangement of vascular bundles. In the petiole, there are three bundles in the base (Fig. 9) and middle regions, and five different-dimensioned bundles in the apex (Fig. 10). The epidermis presents thick-walled tector trichomes with pointed extremities (Fig. 28). The cortical region of the petiole is collenchymatous and parenchymatous (Figs. 9, 10). The petioles of Peperomia hispidula A. Dietr., P. langsdorfii Miq., P. emarginella, P. quadrifolia and $P$. rotundifolia also showed three vascular bundles (Metcalfe \& Chalk 1957; Takemori 2002), although the authors did not indicated the petiole section level. Takemori (2002) recorded a single vascular bundle in the $P$. catharinae petiole.

With reference to the petiole of the other two species, the structural differences of the stem are more significant. Unlike the stem, there is no sclerenchyma in the cortex or in the central cylinder of the petiole (Figs. 11, 13). However, $O$. martiana can present isolated or grouped sclereids in the petiole (Fig. 11). The vascular bundles of the petiole are distributed in a single ring (Figs. 11-13) and not in two concentric rings as in the stem. An endodermis with Casparian strips is not observed in the petiole either. The epidermis of $O$. martiana and P. diospyrifolium presented glandular and tector trichomes similar to those found in the blade (Figs. 29-31, 33, 34).

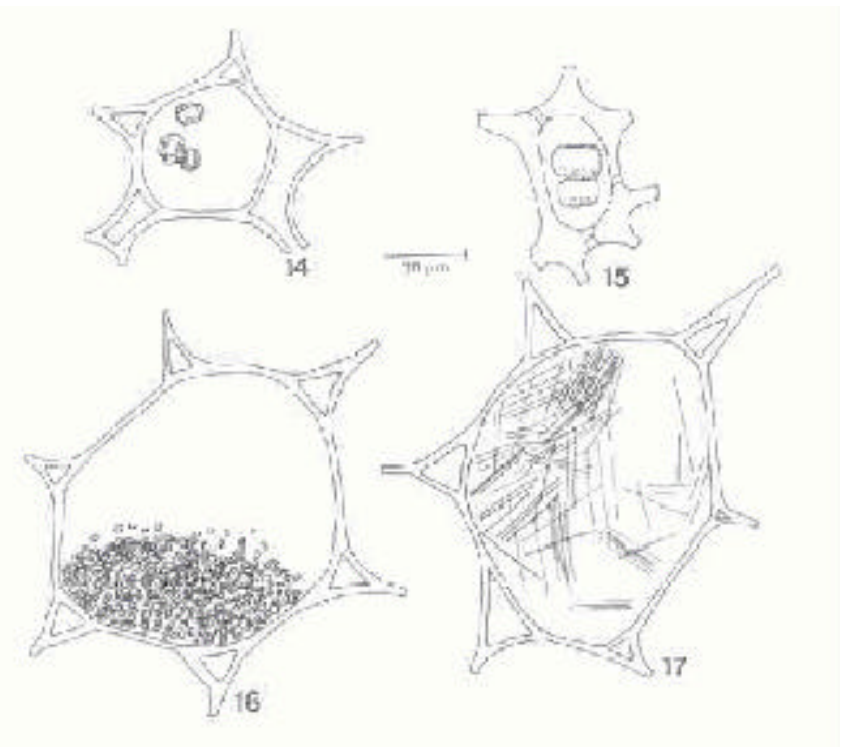

Figures 14-17. Crystals in the petiole cells. Figs. 14, 15 show monocrystals in parenchymatous and collenchymatous cells of P. dahlstedtii. Fig. 16 shows crystal sand in parenchymatous cell of $O$. martiana. Fig. 17 shows raphides in parenchymatous cell of $P$. diospyrifolium. 
Gayana Bot. 61(1), 2004

Elongated parenchymatous cells in the face outside the phloem can occur in the petiole or blade of many plants (Esau 1959). These cells form thick walls after the obliteration of the sieved elements, characterizing the differentiation of collenchymatous or sclerenchymatous tissue. The inner peripherical parenchyma of the xylem can also be differentiated in a similar way (Esau 1959), and this parenchyma can cover the vascular bundle completely like a sheath. In the petiole of $P$. diospyrifolium, parenchymatous cells were observed in the phloem and xylem faces (Figs. 12, 13), whose walls remained thin. On the other hand, in the $O$. martiana petiole, collenchymatous cells were distributed in a similar way in the vascular bundle (Fig. 11).

Crystal and oil cells were found in the leaves of all three species. The crystal cells differ in content and occurrence among the species. In $P$. dahlstedtii, prismatic calcium oxalate monocrystals with a pyramidal base occur in parenchymatous and collenchymatous petiole cells (Figs. 14, 15). In $O$. martiana, the crystal cells are observed in the parenchyma of the petiole and midrib, containing large amounts of silica crystal sand (Fig. 16). In $P$. diospyrifolium, there are cells with calcium oxalate raphides (Fig. 17) in the parenchyma of the petiole and midrib. Metcalfe \& Chalk (1957) reported the presence of the three crystal types in Piperaceae leaves. Crystals resembling sand (as observed in $O$. martiana) were recorded by Metcalfe \& Chalk (1957) in Piper betle L. Gobbi (2003), in turn, found granulated silica crystals in Piper amalago (Jacq.) Yunck. and calcium oxalate raphides in P.arboreum Aubl. and P. crassinervium Kunth..

Oil cells occur in the parenchyma, collenchyma and vascular tissues of the petiole and midrib of all three species. In the blade, they can appear in the mesophyll or subepidermis. Oil secretory cells are common in Piperaceae (Metcalfe \& Chalk 1957; Barroso et al. 1978), i. e. species of Peperomia (Murty 1960; Takemori 2002) and Piper (Nascimento \& Vilhena-Potiguara 1999).

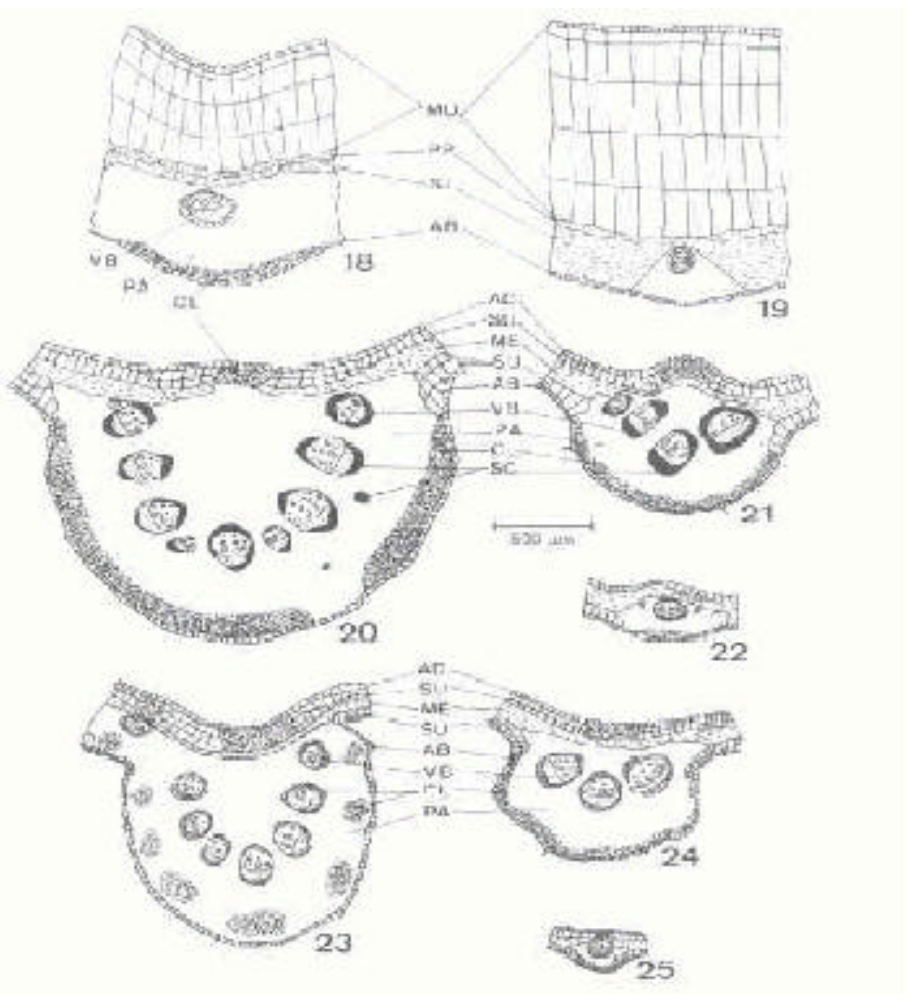

Figures 18-25. Midrib structure in cross-section. Figs. 18, 19 show basal and apical regions of P. dahlstedtii midrib. Figs. 20-22 show basal, middle and apical regions of $O$. martiana; midrib. Figs. 23-25 show basal, middle and apical regions of $P$. diospyrifolium midrib $(\mathrm{AB}=$ abaxial face epidermis, $\mathrm{AD}=$ adaxial face epidermis, $\mathrm{CL}=$ collenchyma, $\mathrm{ME}$ $=$ mesophyll, $\mathrm{MU}=$ multiseriate epidermis, $\mathrm{PA}=$ parenchyma, $\mathrm{PP}=$ palisade parenchyma, $\mathrm{SJ}=$ spongy parenchyma, $\mathrm{SC}=$ sclerenchyma, $\mathrm{SU}=$ subepidermis, $\mathrm{VB}=$ vascular bundle) . 
Vegetative morphology and anatomy of Piperaceae: SouzA, L. ET AL.

The midrib in the leaf base of P. dahlstedtii, unlike the petiole, presents just one vascular bundle (Fig. 18), with a parenchymatous sheath lacking Casparian strips. On the adaxial face of the midrib, a multiple epidermis, palisade parenchyma and a little spongy parenchyma occur (Fig. 18). On the abaxial face, a uniseriate epidermis, collenchyma (with thinner cell walls those the petiole collenchyma) and parenchyma are observed (Fig. 18). In the midrib apex (Fig. 19), there are few cells in the vascular bundle, the adaxial epidermis presents more cellular layers and there are no collenchyma in the abaxial surface.

The midrib in the leaf base of $O$. martiana has 10-11 different-dimensioned collateral vascular bundles, with sclerenchymatous cells in the phloem and xylem faces (Fig. 20). On the abaxial surface of the midrib, an epidermis with tector and glandular trichomes, subepidermic collenchyma strands and parenchyma occurred. On in the adaxial suface, in addition to the epidermis and subepidermis, a few collenchyma, chlorenchyma and parenchyma were observed (Fig. 20). Sclereids occur within the parenchyma tissue of the vein (Fig. 20). The O. martiana midrib undergo structural modifications along the blade: the number of vascular bundles is reduced to three or four in the intermediary region (Fig. 21); to one middle-sized bundle and to two very small bundles in the apical region (Fig. 22).

The $P$. diospyrifolium midrib structure is similar to that of O. martiana. In the former, there are also several vascular bundles in the base, reduced to three in the intermediary portion and to one or two in the apical region (Figs. 23-25). Collenchyma and parenchyma distribution on the abaxial face, and the occurrence of parenchymatous or collenchymatous cells in the vascular bundle of the P. diospyrifolium midrib, are similar to those of the petiole.

The petiole and blade of the studied species do not present an endodermis with Casparian strips, as shown for other Piperaceae (Bond 1931; Lersten 1997; Takemori 2002; Gobbi 2003).
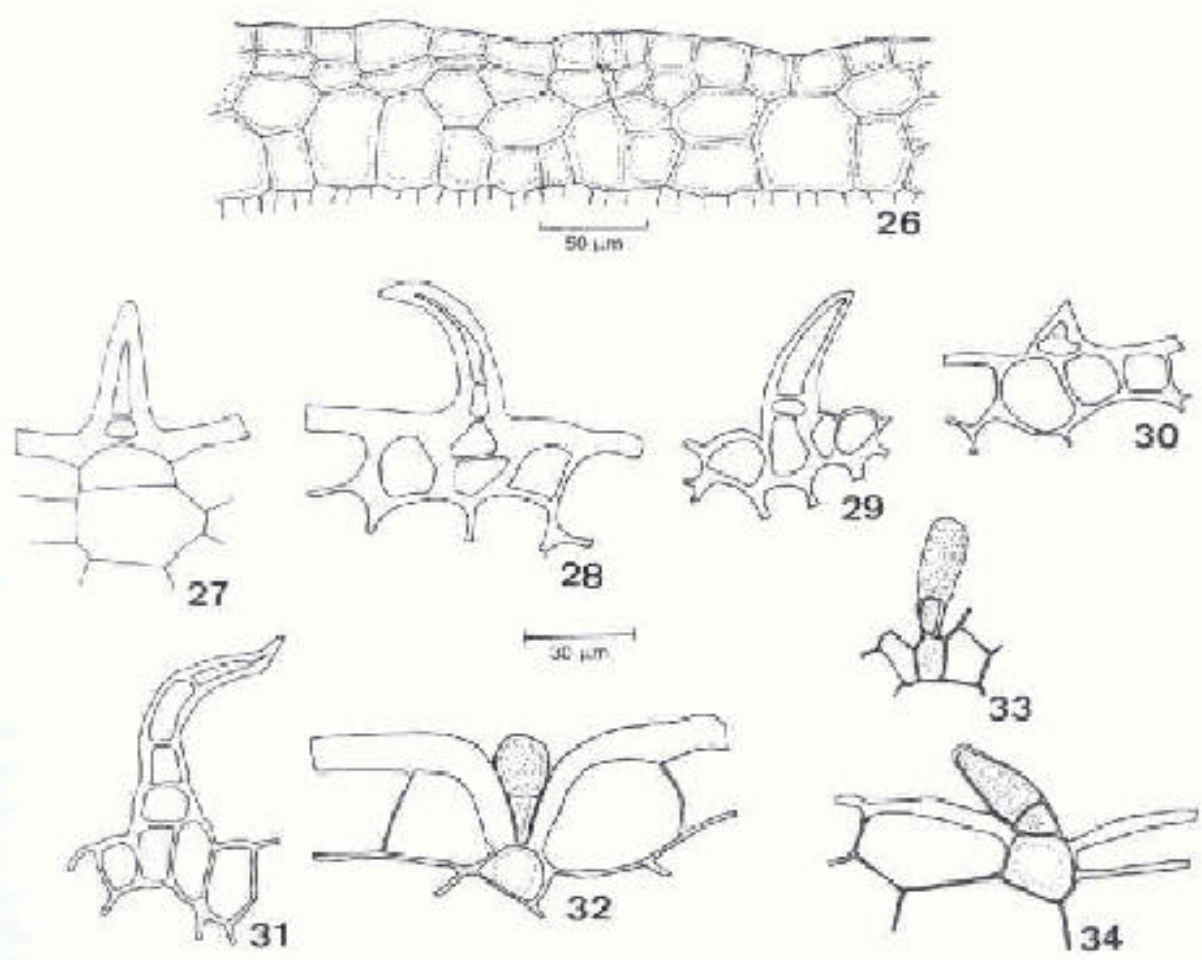

Figures 26-34. Leaf epidermis in cross-section. Figs. 26-28. Young multiseriate epidermis and tector trichomes of $P$. dahlstedtii, respectively. Figs. 29-30. Tector trichomes of $O$. martiana. Fig. 31. Tector trichome of $P$. diospyrifolium. Figs. 32-34. Secretory trichomes of $P$. dahlstedtii, $P$. diospyrifolium and $O$. martiana, respectively. 
Gayana Bot. 61(1), 2004

In all three species, the blade also has glandular trichomes with a unicellular apex and short pedicel (Figs. 32-34). The O. martiana and $P$. diospyrifolium the pedicel occupies the same level of the other epidermic cells (Figs 33, 34), while that of $P$. dahlstedtii occurs in a small depression in the epidermis (Fig. 32). The $O$. martiana and $P$. diospyrifolium the pedicel cell has a somewhat thicker wall (Figs. 33, 34) than in P.dahlstedtii (Fig. 32). The apical cell trichome is spherical in $P$. dahlstedtii (Fig. 32), slightly pointed in O. martiana (Fig. 34) and clavate in P.diospyrifolium (Fig. 33). Tector trichomes with a variable number of cells were present in the blade of the three species (Figs. 27-31), although they are more restricted to the epidermis that covers the midrib in $O$. martiniana and $P$. diospyrifolium. Glandular and tector trichomes similar to those of the study species were also recorded in other Peperomia (Takemori, 2002) and Piper (Nascimento \& Vilhena-Potiguara 1999) species.

The blade epidermis of $P$. dahlstedtii and $P$. diospyrifolium has straight or slightly curved anticlinal cell walls (Figs. 35, 36). The cell walls of the $O$. martiana epidermis are sinuous in both the adaxial and abaxial leaf surfaces (Figs. 37, 38).
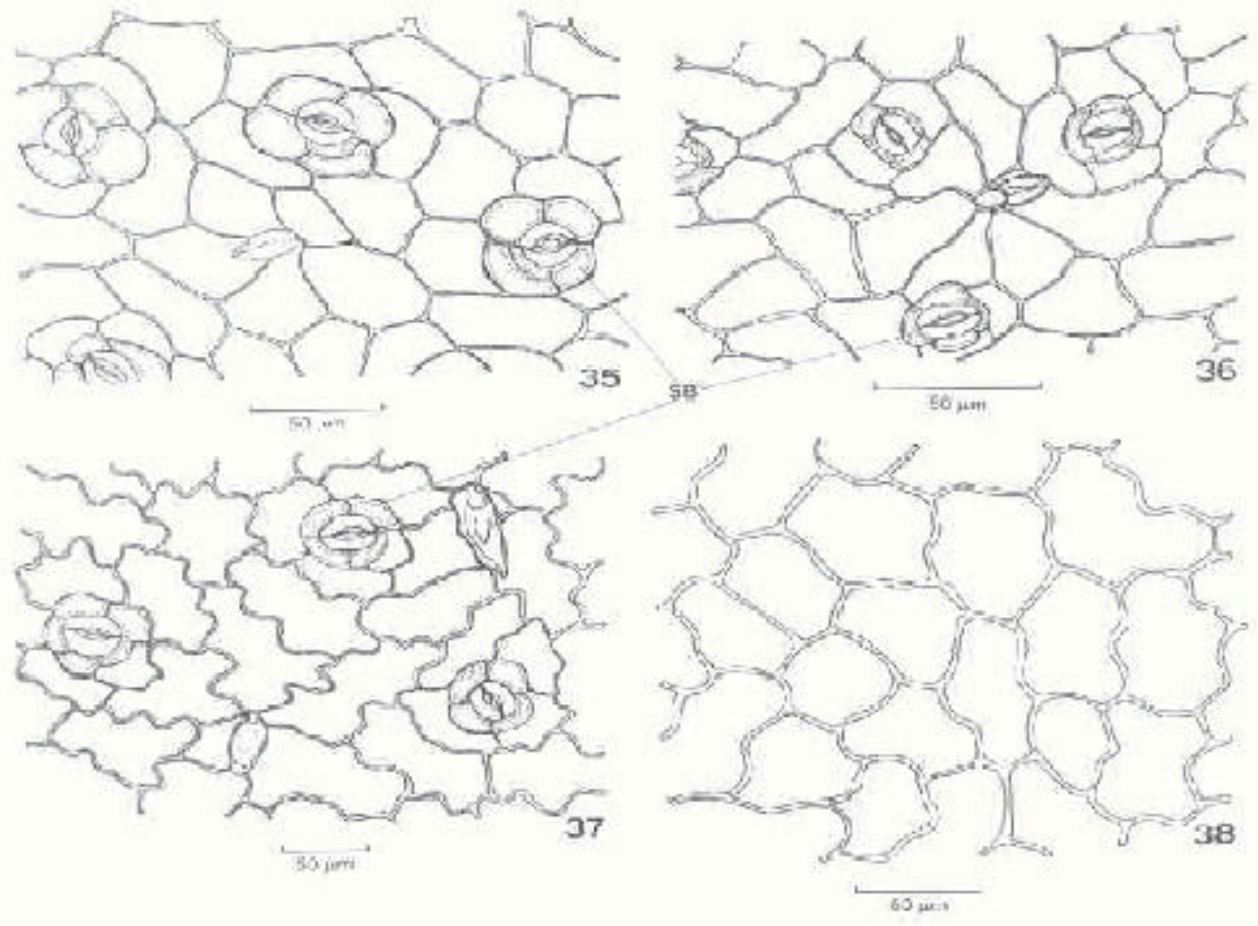

FIgUREs 35-38. Leaf epidermis in frontal view. Figs. 35-37. Abaxial face of $P$. dahlstedtii, $P$. diospyrifolium and $O$. martiana, respectively. Fig. 38. Adaxial face of $O$. martiana. $(\mathrm{SB}=$ subsidiary cell).

Leaves of all three species are hypostomatic (Figs. 35-38), which seems to be common in Piperaceae. However, some species with amphistomatic leaves have been recorded (Metcalfe \& Chalk 1957; Nascimento \& VilhenaPotiguara 1999).

Judd et al. (1999) claimed that tetracytic stomatal complexes are common in the leaf epidermis of Piperaceae species. We did find tetracytic stomatal complexes in P.diospyrifolium
(Fig. 36), and occasionally P. dahlstedtii. However, a staurocytic stomatal complex was found in $O$. martiana (Fig. 37), and often also in $P$. dahlstedtii (Fig. 35). Takemori (2002) mentions types of anisocytic and anomocytic stomatal complexes in other species of the family. Nascimento $\&$ Vilhena-Potiguara (1999) recorded a cyclocytic complex in the Piper hispidinervium leaf, which suggests that this character cannot be applied reliably in Piperaceae taxonomy. 
Vegetative morphology and anatomy of Piperaceae: SouzA, L. ET AL.

O. martiana leaves have lower stomatal, epidermic cell and trichome frequency than the other two species (Table I). However, the data obtained on the leaf epidermis of these plants do not take into consideration environmental conditions such as light and humidity, and intraspecific diversity. Therefore, the data only have value in the characterization of the species and have no taxonomical or ecological importance.

TABLE I. Mean values of stomata, epidermal cells and trichomes $\mathrm{mm}^{-2}$ and stomatal index of leaves of three Brazilian Piperaceae species.

\begin{tabular}{lccccc}
\hline \multirow{2}{*}{ Species } & \multicolumn{3}{c}{ Abaxial face } & \multicolumn{2}{c}{ Adaxial face } \\
\cline { 2 - 6 } & Stomata $\mathrm{mm}^{-2}$ & Epidermic cells $\mathrm{mm}^{-2}$ & Stomatal index & Trichomes $\mathrm{mm}^{-2}$ & Epidermic cells $\mathrm{mm}^{-2}$ \\
\hline Peperomia dahlstedtii & 60.0 & 153 & 5.4 & 11.0 & 832.0 \\
Piper diospyrifolium & 142.5 & 1378 & 9.4 & 10.5 & 940.0 \\
Ottonia martiana & 35.5 & 581 & 5.8 & 2.0 & 642.5 \\
\hline
\end{tabular}

The $P$. dahlstedtii blade shows a multiple epidermis in the adaxial face (Fig. 39), also verified in other Peperomia species (e.g. $P$. catharinae, $P$. emarginella, $P$. quadrifolia and $P$. rotundifolia) (Takemori 2002). The leaf protodermis of these species undergo repeated periclinal divisions (Fig. 26), forming a multiseriate epidermis that functions as a water reserve. Metcalfe \& Chalk (1957) incorrectely referred to this epidermis as hypoderm. The abaxial surface, on the other hand, possess a uniseriate epidermis (Fig. 39).

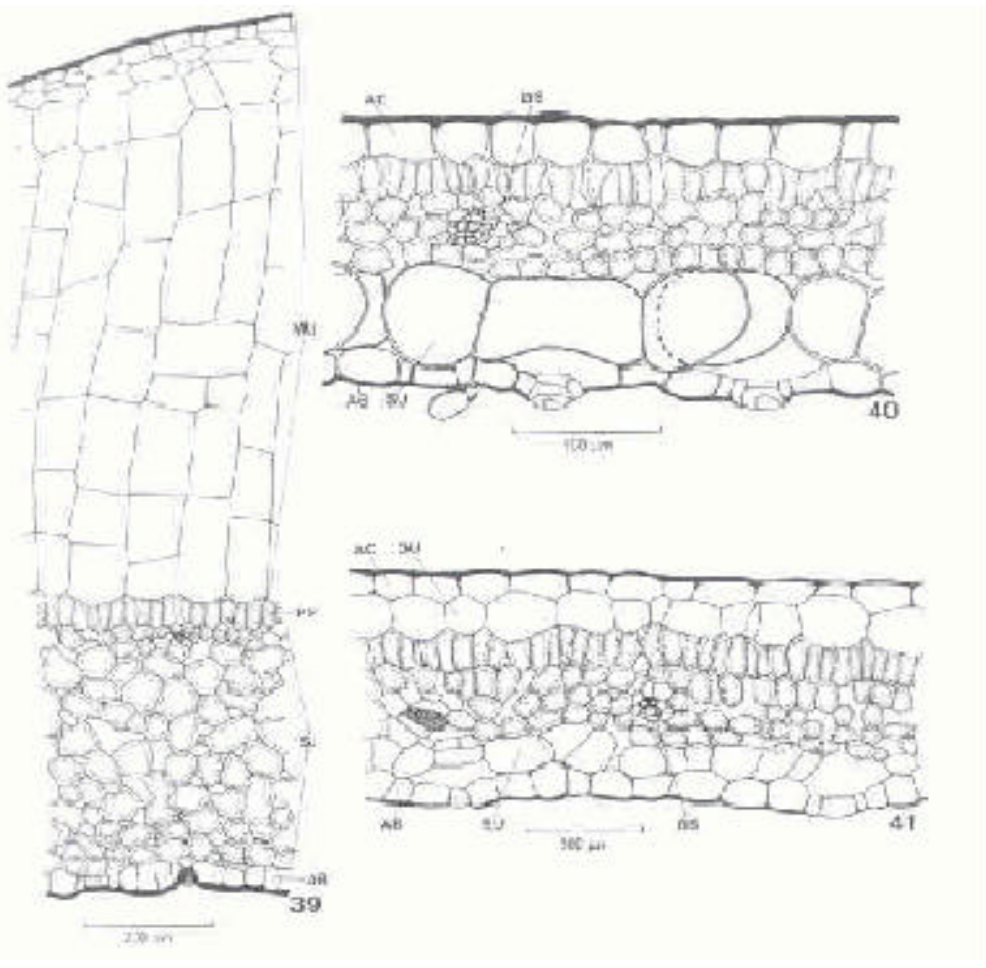

Figures 39-41. Details of leaf blade in cross-section of $P$. dahlstedtii, $O$. martiana and P. diospyrifolium, respectively. $(\mathrm{AB}=$ abaxial face epidermis, $\mathrm{AD}=$ adaxial face epidermis, $\mathrm{BS}=$ bundle sheath, $\mathrm{MU}=$ multiseriate epidermis, $\mathrm{PP}=$ palisade parenchyma, $\mathrm{SJ}=$ spongy parenchyma, $\mathrm{SU}=$ subepidermis). 
Gayana Bot. 61(1), 2004

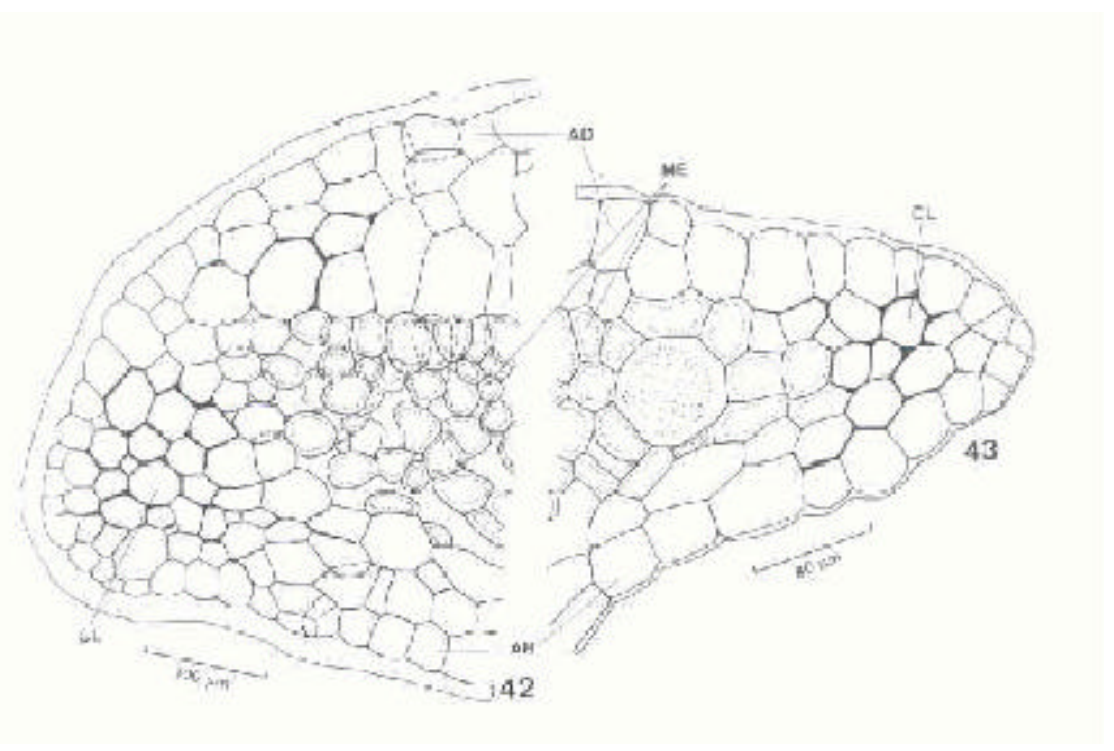

FIGUREs 42-43. Details of blade margin in cross-section of Peperomia dahlstedtii and Piper diospyrifolium. $(\mathrm{AB}=$ abaxial face epidermis, $\mathrm{AD}=$ adaxial face epidermis, $\mathrm{CL}=$ collenchyma, $\mathrm{ME}=$ mesophyll).

The $O$. martiana blade (Fig. 40) presents a uniseriate epidermis and one or two subepidermic layers with enlarged cells in the abaxial face. However, this subepidermis can occur in both faces in the leaf base and in the midrib vicinity (Figs. 20-22). The $P$. diospyrifolium blade has an epidermis and subepidermic layer in both leaf surfaces (Fig. 41). The subepidermic layer of Piper hispidinervium C.DC. was interpreted by Nascimento \& VilhenaPotiguara (1999) as hypoderm, although the authors did not study the origin of this leaf tissue. Metcalfe \& Chalk (1957) also considered the one to numerous layers in Peperomia and Piper leaves as hypoderm. Only leaf development analysis can reveal the nature of this tissue in $O$. martiana and P.diospyrifolium, i.e. having a hypoderm or biseriate epidermis.

The studied plant leaves are dorsiventral (Figs. 39-41), a previously recorded Piperaceae character (Metcalfe \& Chalk 1957). The species have a heterogeneous mesophyll with a single palisade parenchyma layer (Figs. 39-41). P. dahlstedtii shows several spongy parenchyma strata (Fig. 39) and $O$. martiana and $P$. diospyrifolium present three to four layers (Figs. 40, 41). Funnel-shaped palisade cells, observed in Peperomia spp. (Metcalfe \& Chalk 1957; Takemori 2002) and Piper arboreum (Gobbi 2003), were recorded in the mesophyll of the leaf base of $P$. dahlstedtii. In the other leaf regions of this species, the palisade parenchyma cell patterns were closer than in the other two species analyzed. The blade margin is similar in the three study species. It consists of subepidermic cells that contain no chloroplasts and acquire collenchymatous cell walls (Figs. 42, 43).

\section{ACKNOWLEDGMENTS}

We thank UEM (Universidade Estadual de Maringá, Brazil) for funding this research.

\section{BIBLIOGRAFIA}

Barroso, G.M., E.F. Guimarães, C.L.F. Ichaso, C.G. Costa \& A.L. Peiхото. 1978. Sistemática de Angiospermas do Brasil. Volume 1. Livros Técnicos e Científicos Editora e Editora da Universidade de São Paulo. São Paulo. 443 pp.

Bond, G. 1931. The stem endodermis in the genus Piper. Transactions of the Royal Society of Edinburgh 56: 695-724.

Chamberlain, C.J. 1932. Methods in Plant Histology. The University of Chicago Press, Chicago. 416 pp.

Cutler, D. F. 1978. Applied Plant Anatomy. Longman, London. 103 pp.

Datta, P.C. \& A. Dasgupta. 1977. Comparison of vegetative anatomy of Piperales. II. Leaves. Acta 
Vegetative morphology and anatomy of Piperaceae: SouzA, L. ET AL.

Biologica Academiae Scientiarum Hungaricae 28: $97-110$

DNYANSAGar, V.R. 1958. Embryological studies in the Leguminosae VIII. Acacia auriculaeformis A. Cunn., Adenanthera pavonina Linn., Calliandra grandiflora Benth. Lloydia 21:1-25.

EAmes, A.J. \& L.H. MacDaniels. 1953. An Introduction to Plant Anatomy. McGraw-Hill Book Company, New York. 427 pp.

Esau, K. 1959. Anatomía Vegetal. Ediciones Omega, Barcelona. 729 pp.

FAHN, A. 1990. Plant Anatomy. Pergamon Press, Oxford. $588 \mathrm{pp}$.

Font-Quer, P. 1985. Diccionario de Botánica. Editorial Labor, Barcelona. 1244 pp.

Goввi, A.P. 2003. Morfo-anatomia comparativa da folha de três espécies da família Piperaceae. Monografia. Universidade Estadual de Maringá, Maringá.

Johansen, D.A. 1940. Plant Microtechnique. Tata McGraw-Hill Book Company. Bombay. 523 pp.

Judd, W.S., C.S. Campbell, E.A. Kellogg \& P.F. Stevens. 1999. Plant Systematics: a Phylogenetic Approach. Sinauer Associates, Sunderland. $465 \mathrm{pp}$.

Langhammer, V.L. 1970. Piper auritum H.B.K.-an anatomical-histochemical study. Piperaceae used in folk medicine-comparative anatomical-histochemical study I. Planta Medica 19: 63-70.

LeRsten, N.R. 1997. Occurrence of endodermis with a Casparian strip en stem and leaf. The Botanical Review 63: 265-272.

Metcalfe, C.R. \& L. Chalk. 1957. Anatomy of the Dicotyledons - leaves, stem and wood in relation to taxonomy with notes on economic uses. Clarendon Press, Oxford. 1500 pp.
Murty, Y.S. 1960. Studies in the order Piperales - I. A contribution to the study of vegetative anatomy of some species of Peperomia. Phytomorphology 10: $50-59$.

Nascimento, M.E. \& R.C. Vilhena-Potiguara. 1999. Aspectos anatômicos dos órgãos vegetativos de Piper hispidinervium C.DC. (Piperaceae) e suas estruturas secretoras. Boletim do Museu Paraense Emílio Goeldi, série Botânica 15: 39-104.

Rızzinı, C.T. 1977. Sistematização terminológica da folha. Rodriguésia 29: 103-125.

Salatino, A. \& J.B. Silva. 1975. Anatomia e óleo essencial das folhas de Piper regnellii (Miq.) C.DC. var. regnellii. Boletim de Botânica da Universidade de São Paulo 3: 95-106.

SILVA, E.M. J. \& S.R. MACHADO. 1999. Estrutura e desenvolvimento dos tricomas secretores em folhas de Piper regnellii (Miq.) C. DC. var. regnellii (Piperaceae). Revista Brasileira de Botânica 22: 117-124.

TAKEMORI, N.K. 2002. Anatomia comparada de Peperomia catharinae Miquel, P. emarginella (Sw.) C.DC., $P$. quadrifolia (L.) Kunth e P. rotundifolia (L.) Kunth (Piperaceae). Dissertação (Mestrado). Universidade Federal do Paraná, Curitiba.

Wilkinson, H.P. 1979. The plant surface (mainly leaf). In: Anatomy of the dicotyledons (eds. Metcalfe, C. R. \& L. Chalk). pp. 97-165. Clarendon Press, Oxford.

Yuncker, T.G. 1972. The Piperaceae of Brazil - I. Piper - group I, II, III, IV. Hoehnea 2: 19-366.

Yuncker, T. G. 1973. The Piperaceae of Brazil - II. Piper - group V; Ottonia; Pothomorphe; Sarcorhachis. Hoehnea 3: 29-284.

Yuncker, T. G. 1974. The Piperaceae of Brazil III: Peperomia - taxa of uncertain status. Hoehnea 4: 71-413.

Fecha de recepción: 09.12.03

Fecha de aceptación: 16.03.04 